\title{
Актуальні проблеми приклаАного мистецтвознавства крізь призму сучасного законодавства України
}

\author{
ОКСАНА ЦИГАНОК
}

\begin{abstract}
Анотація. Розкрито зміст поняття «прикладне мистецтвознавство», зроблена спроба опису його завдань та вказано на його прямий зв'язок із правовим полем, поставлено питання термінологічної невіАповіАності понять у законодавстві України.

Ключові слова: прикцадне мистецтвознавство, культурні цінності, юридична термінологія, законодавство України.
\end{abstract}

Постановка проблеми. Мистецтвознавство - порівняно молода галузь гуманітарних знань, але її Аиференціація неминуча. Нині скмалася ситуація, коли кмасичне мистецтвознавство не охоплює наявний масив практичних завдань, пов'язаних з мистецтвом.

Отже, виникає потреба в близькій Аисципліні приклаАного спрямування, яка б обслуговувала рух та обіг культурних цінностей. Ці процеси неможииві без грамотного юридичного супроводу. Українське правове поле в сфері культурних цінностей на сьогоАні знаходиться в зародковому стані. В законах присутні очевиАні Авозначності, могічні невіАповідності та навіть неАотримання мовних вимог Ао наукової термінології. ВіАсутність єАиного понятійного апарату ускцаАнює процес тлумачення. Термінологічні колізії часто унеможиивлюють застосування правових норм у цій галузі. У зв'язку з очевиАністю вищезазначених проблем дана розвідка $\epsilon$ актуальною.

Анаміз останніх досліАжень і публікацій. АосліАження бібліографії велося в Авох основних напрямках. По-перше, анацізувацися інформаційні джерела, які описують ета- пи формування науки мистецтвознавства, Аають визначення та окреслюють мету й завдання цієї науки на Ааному етапі розвитку. ПоАруге, аналізувалося актуальне законодавство України у сфері кумьтури та мистецтва, а також міжнародні правові зобов'язання України в цій сфері.

Перший інформаційний блок формувався протягом кількох сотень років, тому вельми обширний. Праці Генріха Вемьфміна [4], Бернарда Беренсона [30, 31], Бориса Віппера [5], Жана Базена [2], які, в свою чергу, базуються на наукових розробках Платона, Арістотеля, Вітрувія, Павсанія, Вазарі, Альберті, Вінкемьмана, Ае Кейлюса та інших вчених, сформулювали сучасне «триєАине» трактування поняття «мистецтвознавство».

Що стосується анацізу сучасного стану мистецтвознавства, то він носить констатаційнотеоретичний характер. Тобто констатуються зміни у методології трьох напрямків мистецтвознавства, піАвоАяться теоретичні засаАи піА ці зміни, але ігнорується потреба коригування та поглиблення самого визначення поняття «мистецтвознавство». 
Винятком є стаття Оксани Бойко «ПриклаАное искусствовеАение или искусствоведение на практике», опубцікована 2015 року [3]. В цій роботі зАійснено спробу виАілити прикмаАну скмадову мистецтвознавства та схематично окреслена сфера її застосування.

Аругий інформаційний блок скмадається із законів та нормативних актів [9-11, 14, 15, 18-24], оскільки мише законодавчо закріп ені визначення понять $\epsilon$ піАставою Аля зАійснення тих чи інших правочинів з предметами мистецтва та комекціонування. Корисна інформація з теорії та практичної Аії цих нормативно-правових актів міститься в низці спеціалізованих публікацій. Перш за все, мова йде про етапну монографію професора Віктора Акуленка «Міжнародне право охорони культурних цінностей та його імплементація у внутрішньому праві України» [1] - це перше і поки єАине виАання, в якому сформульована концепція становцення та розвитку міжнародного права охорони культурних цінностей. Сергій Кот у 2016 році зАійснив публікацію, в якій, усліА за професором Акуленком, озвучує теоретичну проблему невизначеності поняття та терміна «культурні цінності» [12]. ОАнак, робить наголос на аналізові поняття «культура» як на первинному щодо поняття «кукьтурні цінності».

Питання термінології порушують мистецтвознавці ГАіб Вишеславський та Олег СиАор-Гібелинда, укмадачі словника «Терміномогія сучасного мистецтва» [6].

Крім того, термінологія з теми Ааного АосліАження подається у «САовнику термінів мистецтвознавця-експерта», піАготовленого та виАаного НАКККІМ ААя стуАентів спеціальності «мистецтвознавець-експерт» [28].

Світлана Шман у своєму Аослідженні ана^ізує культурологічні аспекти Аержавної експертизи культурних цінностей в Україні [29]. Практичні розробки професорів Степана Максимова [13], Бориса Пиатонова [17], Володимира Індутного [16] в сфері оцінки матеріальних культурних цінностей спираються на діюче законодавство та цілком залежать віА його норм, віАповідно, оперують наявною термінологією.

Професор Віктор Карпов акцентує увагу на специфіці державної політики в сфері наАання послуг з експертизи культурних цінностей, а також на особливостях імпортно-експертних операцій на ринку культурних цінностей на основі існуючого законодавства [7; 8]. Констатується величезна необхідність зміни законодавчих актів.

Метою цієї статті $\epsilon$ обгрунтування необхіАності введення в науковий обіг поняття «прикмадне мистецтвознавство», опис його завдань та окреслення сфери його застосування. А також підняття питання оновлення та редагування термінології вітчизняного законодавства у сфері культурних цінностей.

Викмад основного матеріалу. Інтерес Ао мистецтва та намагання осягнути його суть і стійкі тенденції супроводжуваци АюАину віА часів отримання першого естетичного задоволення. Аце як наука, тобто з вцасним понятійним апаратом та методологією, мистецтвознавство постало відносно недавно, час формування знаходиться на межі XVII та XVIII століть, інтенсивний розвиток - на межі XIX та XX століть. У ці періоди виникми й отримали обгрунтування основні напрямки науки про мистецтво:

- історія мистецтва;

- теорія мистецтва;

- художня критика [20, с. 57-59].

На сьогодні очевиАно, що теоретичне мистецтвознавство (авторка використовує це поняття на означення кцасичного уяв ення про мистецтвознавство, як триєАність «історія - теорія - критика») знаходиться у кризовому стані. Ймовірно, це пов'язано з глобальним вихоАом преАмета мистецтва зі сфери ІАей у сферу насампереА Речей, а вже потім ІАей.

Отож, на сьогодні спостерігаємо, що історія мистецтва обмежена застарікими методами пізнання; теорія мистецтва використовує безліч термінів суміжних Аисциплін, але все 
одно не дає відповіді на базові питання. НаприклаА: ЩО є мистецтвом? Художня критика взагаці перестає бути розАілом мистецтвознавства та тяжіє Ао художніх практик. Втім, опис та оцінка трансформацій способів суспільного художнього мислення - зона віАповіАацьності філософії та естетики і не $є$ завданням цього Аослідження.

Якщо осмислювати мистецтвознавство винятково як історію мистецтва, теорію мистецтва та художню критику, вочевидь стає зрозумілим, що в реаліях сучасності «за бортом» науки опиняється цілий комплекс виАів Аіяльності, які фактично забезпечують існування ринку (як мегального, так і тіньового) предметів мистецтва, але формально вони стосуються інших галузей знань та вмінь. Аише прикцаАка «арт» часом натякає на дотичність до сфери мистецтва, наприкмаА, «арт-Аилер», «артменеАжер» тощо.

Прикмадне, або практичне мистецтвознавство - комплекс напрямків, які на практиці застосовують знання історії мистецтва, теорії мистецтва та художньої критики [3], оАночасно $є$ Ажерелом їх поповнення й забезпечують функціонування ринку преАметів мистецтва та колекціонування. Крім того, вони організаційно та технічно забезпечують сам процес створення мистецтва. У цьому полягає мета практичного мистецтвознавства.

Поява прикладного мистецтвознавства $\epsilon$, з оАного боку, природним процесом Аиференціації науки, а з іншого боку, закономірним результатом інтеграції гуманітарних, суспільних, природничих та формальних наук.

СереА виАів прикладного мистецтвознавства пропонуємо видікити наступні:

- мистецтвознавча експертиза;

- оцінка предметів мистецтва та колекціонування;

- реставрація предметів мистецтва та колекціонування;

- кураторство і технічна організація художніх виставок;
- арт-Аилерство;

- галерейна справа;

- аукціонна діяльність;

- юридичне забезпечення руху й обігу преАметів мистецтва та колекціонування;

- охорона і страхування предметів мистецтва та колекціонування;

- логістика;

- реклама;

- тощо, а також будь-яке поєАнання цих напрямків.

Частково функції напрямків практичного мистецтвознавста знаходяться на перетині 3 функціями арт-менеджменту, але ці поняття є саме пересічними, а не тотожними чи виАовими та родовими.

Як уже зазначалося, будь-які правочини 3 предметами мистецтва та колекціонування можуть зАійснюватися винятково на основі Аiючого законодавства. Але тут юристів чекають Аогічні та $\Lambda$ інгвістичні сюрпризи.

«ОАнією із важливих особливостей мови законів має бути їх точність і доступність, стисАість і зрозумілість Аля громаАян. Формування мовного стилю законів має суттєве значення А я їх тлумачення, правозастосовної практики, а у кінцевому підсумку - Аля стабілізації законодавства» [1, с. 475].

У законотворчій сфері використовується тільки офіційно-Аіловий стиль мовлення, найбільш регламентований та стандартизований. Базовою беззаперечною вимогою $є$ використання сучасної української мітературної мови з суворими обмеженнями Аопустимої мексики. Існує абсолютна заборона на Аіалектизми, жаргонізми та просторічну мексику, емоційно забарвлені вирази. ААже нормативний акт покмиканий впливати не на почуття та уяву, а апелювати до інтелекту та волі суб'єктів права. Він мусить приписувати їм певну поведінку, звіАси гранична чіткість і повнота формумювань, сувора послідовність викмаду, високий рівень одноманітності, стандарти форми викладу інформації. 
За таких обставин особливого значення набувають вимоги Ао спеціальної термінології, що нею оперує мова законів. Терміни в законі - це слова чи вирази, які означають максимально точно визначене поняття, і тільки його. Неприпустимо, щоб через некоректність термінології в залежності віА контексту змінюваАися юриАичні поняття. Найважливішою вимогою Ао стабільного законодавства $є$ термінологічна єАність. На жаль, Аіюче нині законодавство Аемонструє, швиАше, термінологічне розмаїття та непослідовність. Причому, це однаково стосується як внутрішнього законодавста, так і міжнародного.

Значення базових понять «культура», «цінності», «культурні цінності», «мистецтво», «твори мистецтва» не є унормованим. На думку Сергія Кота, культура дотепер не має єАиного універсального визначення й по-різному трактується окремими Аослідниками, залежно віА пропонованих піАходів щодо широти охоплюваних ними явищ [12]. Найширше концептуальне трактування може прозвучати взагаАі як: культура - процес і результат АюАської Аіяльності, відповіАно продукти культури можуть бути матеріальними та нематеріальними. «Цінність» в найширшому філософсько-

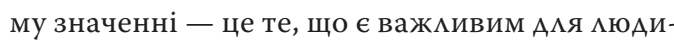
ни чи груп мюдей і задовольняє їхні потреби, бажання, інтереси. Отже, так само може мати матеріацьне чи нематеріальне втілення. Важмиво, що цінності не $є$ константою.

«Культурні цінності»- центральне поняття, яким оперує мова закону та яке $\epsilon$ кмючовим Аля Ааного Аослідження.

Термінологія внутрішнього законодавства в сфері культури так чи інакше базується на міжнародному законодавстві, зокрема за основу взято «Конвенцію про заходи, спрямовані на заборону та запобігання незаконному ввезенню, вивезенню та передачі права вцасності на кумьтурні цінності» (1970) [10]. Втім, Віктор Акуленко, цитуючи німецького правника РуАольфа Аольцера, зазначає, що навіть держа- ви-чмени $\mathrm{CC}$, незважаючи на регіональну одноріАність, не змогли Аосягти єАності щодо змісту поняття культурних цінностей [1, с. 485].

Сергій Кот стверАжує на досвіАі розробки міжнародно-правових норм і внутрішнього законодавства окремих країн, що кожна конвенція чи рекомендація, законодавчий акт дає своє визначення й перелік категорій культурних цінностей, який не $є$ універсальним, а застосовується Аля мети Ааної конвенції, рекомендації, закону [12].

Перше вітчизняне юридичне визначення культурних цінностей містилося у ст. 14 «Основ законодавства України про культуру» (1992) [15]. ЗгіАно з ним, «до культурних цінностей належать об'єкти матеріальної і духовної культури, що мають художнє, історичне, етнографічне та наукове значення. Унікацьні цінності матеріальної та Ауховної культури, а також культурні цінності, що мають виняткове історичне значення Аля формування націонацьної самосвідомості українського нароАу, визнаються об'єктами національного кумьтурного надбання і заносяться до Аержавного реєстру націонацьного культурного надбання».

Згодом це поняття було закріплене в Конституції України (1996). В ст. 54 містилося вже Ава терміни: культурні цінності та культурна спадщина.

Аеталізацію терміна «культурні цінності» знаходимо у ст. 1 Закону України «Про вивезення, ввезення та повернення культурних цінностей» (1999): культурні цінності - це об'єкти матеріацьної та Ауховної культури, що мають художнє, історичне, етнографічне та наукове значення і піАлягають збереженню, віАтворенню та охороні віАповіАно Ао законодавства України, а саме:

- оригінальні художні твори живопису, графіки й скульптури, художні композиції та монтажі з будь-яких матеріалів, твори декоративно-прикмаАного і традиційного народного мистецтва;

- предмети, пов'язані з історичними подія- 
ми, розвитком суспільства і держави, історією науки та культури, а також такі, що стосуються життя й Аіяльності виАатних Аіячів держави, політичних партій, громаАських і релігійних організацій, науки, культури та мистецтва;

- предмети музейного значення, знайдені піА час археологічних розкопок;

- скмадові частини та фрагменти архітектурних, історичних, художніх пам'яток і пам'яток монументального мистецтва;

- старовинні книги й інші видання, що становцять історичну, художню, наукову та $\Lambda$ ітературну цінність, окремо чи в колекції;

- манускрипти й інкунабули, стародруки, архівні документи, вкцючаючи кіно-, фото- і фонодокументи, окремо чи в колекції;

- унікальні та рідкісні музичні інструменти;

- різноманітні види зброї, що має художню, історичну, етнографічну та наукову цінність;

- ріАкісні поштові марки, інші філателістичні матеріали, окремо чи в колекції;

- рідкісні монети, ордени, меАалі, печатки й інші преАмети комекціонування;

- зоологічні колекції, що становлять наукову, культурно-освітню, навчально-виховну або естетичну цінність;

- рідкісні колекції та зразки флори й фауни, мінералогії, анатомії та палеонтології [18].

На сьогодні в Україні це єАиний Аіючий нормативно-правовий акт, у якому міститься визначення поняття «культурна цінність». ОАнак, залишається кілька нез'ясованих питань.

НаприкмаА, у визначенні вказано: «Кумьтурні цінності - це об'єкти матеріацьної та Ауховної культури, що мають художнє, історичне, етнографічне та наукове значення...», однак разом з тим це очевиАна тавтологія, оскільки Ауховна культура якраз і об'єАнує художні, історичні, етнографічні, наукові та інші подібні зАобутки соціального суб'єкта.

Аахі по тексту використовуються поняття, значення яких не конкретизовано. НаприкцаА, як розуміти вислів «оригінальні художні твори»? Як ті, що створені самостійно, без наслі-
Аування відомих зразків? Чи як ті, які $є$ незвичайними, своєріАними?

Аивує вираз «твори траАиційного народного мистецтва». Аосі чітко не визначена суть загального поняття «мистецтво», аце негласно прийнято вважати буАь-який результат творчості, заявлений автором як художнє висловАювання, таким. У Ааному випадку у формумюванні спостерігаємо використання спекуАятивного видового терміна.

Ще одним прикладом плутанини у форму$\Lambda$ юваннях $\epsilon$ поняття «преАмет музейного значення». На Аумку Фаїни Рябчикової, його визначення як «кумьтурної цінності» не віАповіАає засадам музейної науки [25]. Аослідниця вичерпно обгрунтовує свою позицію та рекоменАує переглянути вказані правові дефініції на законодавчому рівні.

СереА перелічених у законі видів культурних цінностей $є$ також «скмаАові частини та фрагменти архітектурних, історичних, художніх пам'яток і пам'яток монументального мистецтва». «Архітектурні пам'ятки» та «історичні пам'ятки», ймовірно, значать віАповіАно: «високохудожній архітектурний твір, збудований у минукі історичні періоди, понаА $40-50$ років тому» та «визначні місця, пов'язані з важиивими історичними подіями, 3 життям та Аіяльністю відомих осіб, культурою та побутом народів». ОАнак поняття «пам'ятка монументального мистецтва» відноситься Ао поняття «архітектурна пам'ятка» як видове до родового. А поняття «художня пам'ятка» взагаАі заАишається загаАкою.

У пункті «старовинні книги й інші видання, що становцять історичну, художню, наукову та $\Lambda$ ітературну цінність, окремо чи в комекції» знову спостерігаємо тавтологію. Причому поАвійну. 3 одного боку, зайве повторення «станов ять історичну, художню, наукову цінність», позаяк це вже зазначено у визначенні вище. А з іншого, означення «літературна цінність» $\epsilon$ видовим поняттям «художньої цінності». 
Як виА культурних цінностей зазначаються «унікальні та рідкісні музичні інструменти». Поняття унікацьності не визначене. Й еться про «наАзвичайний у якомусь віАношенні; ріАкісний, винятковий», як рекомендує сучасний академічний тлумачний словник? Чи первинне значення - «єАИний у своєму роАі»? Знову ж таки, якщо «ріАкісний», то наскільки?

Пункт «різноманітні види зброї, що має хуАожню, історичну, етнографічну та наукову цінність» містить традиційну тавтологію відносно визначення вище.

Такі види культурних цінностей, як "ріАкісні поштові марки, інші філателістичні матеріаци, окремо чи в колекції», «ріАкісні монети, ордени, медалі, печатки й інші преАмети колекціонування» та "рідкісні колекції та зразки фмори й фауни, мінералогії, анатомії та палеонтології» знову містять невизначене поняття ріАкісності.

Вираз-уточнення «окремо чи в колекції» використовується стосовно об'єктів фікате^іï, старовинних книг й інших цінних видань, манускриптів й інкунабул, стародруків, архівних Аокументів вкАючно з кіно-, фото- і фотоАокументами. Щодо об'єктів нумізматики, фамеристики чи сфрагістики він не застосовується. Якщо це несуттєве зауваження, то Аогічно його упустити. Якщо суттєве, то, напевне, сліА його вичерпно обгрунтувати.

Проаналізовано мише формулювання визначення культурних цінностей, що міститься у ст. 1 Закону України «Про вивезення, ввезення та повернення культурних цінностей», але цього цілком досить, щоб віАзначити віАсутність вичерпного визначення цього поняття та уніфікованих дефініцій, які 6 розкрива-
$\Lambda$ його зміст. Загалом текст Закону пістрявіє смисловими невіАповіАностями й порушеннями мовних законів, та найголовніше, він Аопускає подвійне, а то й потрійне тлумачення.

Висновки. Темпи диференціювання сучасних наук надзвичайно високі. Мало не щопівроку на перетині існуючих виникають нові напрямки наукових Аосліджень, які за умови наявності перспективи розвитку швиАко оформлюються в самостійні галузі знань. Мистецтвознавство, на Аумку авторки, Аавно потребує Аиференціювання. Цікий пласт теоретичних та практичних знань не охоплюється сучасним поняттям мистецтвознавство, тому бачиться нагальною потреба професійного обговорення, наукової Аискусії з метою редагування Аефініцій та визначень.

ПриклаАне мистецтвознавство слугує руху та обігу кумьтурних цінностей. А отже, потребує нормативно-правового базису. Це одна з основних пробцем, оскільки внутрішнє законодавство через невпорядкованість термінології не гарантує чіткого тлумачення, Аопускає Авозначності і, як наслідок, спірні моменти при здійсненні правочинів. Нестабільне законодавство є недієздатним.

Проблема полягає як у якості смислового наповнення правових актів у сфері культури, так і в якості формального прояву. Подібні скцаАності можуть бути подолані при замученні Ао написання правових документів спеціалістів різного профілю: правників, теоретиків та практиків мистецтва, Аінгвістів. При такому підході можна забезпечити вичерпне змістове наповнення документа та $\Lambda$ тературно-мовну досконалість. 


\section{Мітература}

1. Акуленко B. I. Міжнародне право охорони культурних цінностей та його імплементація у внутрішньому праві України: моногр. Київ: ТОВ «ВО «Юстініан», 2013. 616 с.

2. Базен Ж. История истории искусства: От Вазари до наших Аней. Москва: Прогресс-Культура, 1994. $528 \mathrm{c}$.

3. Бойко О. В. Прикмадное искусствоведение, или искусствоведение на практике // Universum: Филология и искусствоведение: электрон. научн. журн. 2015. № 3-4 (17). URL: http://7universum.com/ ru/philology/archive/item/2088 (дата обращения: 03.08.2018).

4. Вельблин Г. Основные понятия истории искусств. Пробцемы эволюции стиця в новом искусстве. Москва, 2009. 62 с.

5. Виппер Б. Введение в историческое изучение искусства. Москва: ИзА. В. Шевчук, 2010. 368 с.

6. Вишеславський Г., Сидор-Гібелинда О. Термінологія сучасного мистецтва: словн. Київ, 2010. 416 с.

7. Карпов В. В. Аержавна політика у сфері надання послуг з експертизи культурних цінностей // Вісник НАККІМ. Київ: Мікеніум, 2017. № 2. С. 19-26.

8. Карпов В. В. Імпортно-експортні операції на ринку культурних цінностей // Вісник НАККІМ. 2017. № 3. C. $12-16$.

9. Конвенция о защите культурных ценностей в случае вооруженного конфликта: Гаага, 14 мая 1954

г.: Аок. 995_157, текущая ред. прин. от 14.05.1954. URL: http://zakon5.rada.gov.ua/laws/show/995_157 (Аата обращения: 21.07.2018).

10. Конвенція про заходи, спрямовані на заборону та запобігання незаконному ввезенню, вивезенню та передачі права власності на культурні цінності: 14 лист. 1970 р.: Аок. 995_186, чинний, поточна реА., ратиф. віА 10.02.1988, піАст. 5396-11 URL: http://zakon2.rada.gov.ua/laws/show/995_186 (дата звернення: 18.07.2018).

11. Конвенція про охорону всесвітньої культурної і природної спадщини ЮНЕСКО: міжнар. Аок. віА 16.11.1972. URL: http://zakon4.rada.gov.ua/laws/show/995_089 (Аата звернення: 08.07.2018).

12. Кот С. І. «Культурні цінності»: поняття і термін у контексті повернення та реституції преАметів кумьтури // Праці Центру пам'яткознавста. 2011. Вип. 20. С. 10-26.

13. Максимов С. Й. Національні стандарти оцінки: необхідність змін та Аоповнень: виступ на засіданні круглого столу «Засади формування концептуальних підходів до створення системи Національних стандартів оцінки майна та майнових прав» 14 мипня 2011 p. URL: http://www.vikno. com.ua/altfm/viewtopic.php?p=88375\#88375 (Аата звернення: 22.07.2018).

14. Міжнародні документи [конвенції, хартії, рекомендації з питань охорони культурних цінностей] // Пам'яткознавство: правова охорона культурних надбань: зб. Аок. / Ін-т культурол. Акад. мист. України. Київ, 2009. С. 220-360.

15. Основи законодавства про культуру: Закон України віА 14.02.1992 № 2117-XII, втрата чинності віА 12.01.2011, піАст. 2778-17. URL: http://zakon2.rada.gov.ua/laws/show/2117-12 (Аата звернення: 11.07.2018).

16. Оцінка культурних цінностей / В. В. Індутний та ін. Київ: ТОВ «Аякс Прінт», 2006. 608 с.

17. Платонов Б. О. Аналіз прибутковості творів мистецтва // Вісник НАКККІМ. 2017. № 1. С. 86-90.

18. Про вивезення, ввезення та повернення культурних цінностей: Закон України від 21 вер. 1999 р. № 1068-XIV, реА. віА 06.08.2014, піАст. 1253-18. URL: http://zakon2.rada.gov.ua/laws/show/1068-14 (Аата звернення: 12.07.2018).

19. Про затверАження Порядку проведення Аержавної експертизи культурних цінностей та розмірів плати за ії проведення: пост. КМ України віА 26 серп. 2003 р. № 1343: реА. віА 17.04.2013, піАст. 2332013п. URL:http://zakon3.rada.gov.ua/laws/show/1343-2003-\%D0\%BF (Аата звернення: 16.07.2018).

20. Про культуру: Закон України віА 14.12.2010 № 2778-VI: реА. віА 02.08.2018, піАст. 2481-19. URL: http://zakon2.rada.gov.ua/laws/show/2778-17 (Аата звернення: 11.07.2018). 
21. Про музеї та музейну справу: Закон України віА 29.06.1995 № 249/95-ВР: реА. віА 24.02.2016, піАст. 955-19. URL: http://zakon3.rada.gov.ua/laws/show/249/95-\%D0\%B2\%D1\%80 (Аата звернення: 09.07.2018).

22. Про охорону культурної спадщини: Закон України віА 08.06.2000 р. чинний, поточна реА. 14.03.2018, підст. 2289-19. URL: http://zakon5.rada.gov.ua/laws/show/1805-14 (Аата звернення: 01.07.2018).

23. Про судову експертизу: Закон України віА 25 кют. 1994 р. № 4038-XII, реА. віА 20.01.2018, піАст. 2249-19. URL: http://zakon2.rada.gov.ua/laws/show/ru/4038-12 (Аата звернення: 23.07.2018).

24. Рамкова конвенція Ради Європи про значення культурної спадщини Аця суспільства: міжнар. Аок. віА 27.10.2005: Аок. 994_719, чинний, поточна реА., ратиф. віА 19.09.2013, піАст. 581-18. URL: http:// zakon5.rada.gov.ua/laws/show/994_719 (Аата звернення: 24.07.2018).

25. Рябчикова Ф. А. ТАумачення «преАмета музейного значення» та «музейного преАмета» як культурних цінностей в українському законодавстві: музеологічний аналіз // Праці Центру пам'яткознавства: зб. наук. пр. Київ, 2015. Вип. 28. С. 36-46.

26. Сидор-Гібелинда О. Аоповнення до словника термінів сучасного мистецтва // Сучасне мистецтво. 2012. Вип. 8. С. 304-308.

27. Сидор-Гібелинда О. Аоповнення до словника термінів сучасного мистецтва // Сучасне мистецтво. 2013. Вип. 9. С. 135-142.

28. Словник термінів мистецтвознавця-експерта: Аля стуА. спец. 8.02020501 «Мистецтво», спеціаліз. «Мистецтвознавець-експерт, оцінювач» / укцаА.: В. А. Сіверс, Б. О. Платонов, Н. І. Кравченко [та ін.]. Київ: НАКККіМ, 2011. 124 с.

29. Шман С. Ю. Культурологічні аспекти державної експертизи культурних цінностей в сучасній Україні: Аис. ... канА. культ.: 26.00.01 - теорія та історія культури. Київ: НАККІМ, 2013. 192 с.

30. Berenson B. The study and criticism of Italian art. London: G. Bell and sons, 1902. 260 p.

31. Berenson B., Franchi R. Metodo e attribuzioni. Firenze: Arnaud, 1947. 233 p.

\section{References}

1. Akulenko V. I. Mizhnarodne pravo oxorony` kul` turny`x cinnostej ta jogo implementaciya u vnutrishn`omu pravi Ukrayiny`: monogr. Ky`yiv: TOV «VO «Yustinian», 2013. 616 s.

2. Bazen Zh. Istoriya istorii iskusstva: Ot Vazari do nashih dney. Moskva: Progress-Kultura, 1994. 528 s.

3. Boyko O. V. Prikladnoe iskusstvovedenie, ili iskusstvovedenie na praktike // Universum: Filologiya i iskusstvovedenie: elektron. nauchn. zhurn. 2015. \# 3-4(17). URL: http://7universum.com/ru/philology/ archive/item/2088 (data obrascheniya: 03.08.2018).

4. Velflin G. Osnovnyie ponyatiya istorii iskusstv. Sankt-Peterburg, 1994. $20 \mathrm{~s}$.

5. Vipper B. Vvedenie v istoricheskoe izuchenie iskusstva. Moskva: Izd. V. Shevchuk, 2010. 368 s.

6. Vy`sheslavs`ky`j G., Sy`dir-Gibely`nda O. Terminologiya suchasnogo my`stecztva: slovn. Ky`yiv, 2010. 416 s.

7. Karpov V. V. Derzhavna polity`ka u sferi nadannya poslug z eksperty`zy`kul`turny`x cinnostej // Visny`k NAKKIM. Ky`yiv: Milenium, 2017. \# 2. S. 19-26.

8. Karpov V. V. Importno-eksportni operaciyi na ry`nku kul`turny`x cinnostej // Visny`k NAKKIM. 2017. \# 3. S. $12-16$.

9. Konventsiya o zaschite kulturnyih tsennostey v sluchae vooruzhennogo konflikta: Gaaga, 14 maya 1954 g.: dok. 995_157, tekuschaya red. prin. ot 14.05.1954. URL: http://zakon5.rada.gov.ua/laws/show/995_157 (data obrascheniya: 21.07.2018).

10. Konvenciya pro zaxody`, spryamovani na zaboronu ta zapobigannya nezakonnomu vvezennyu, vy`vezennyu ta peredachi prava vlasnosti na kul turni cinnosti: 14 ly`st. 1970 r.: dok. 995_186, chy`nny`j, potochna red., raty`f. vid 10.02.1988, pidst. 5396-11. URL: http://zakon2.rada.gov.ua/laws/ show/995_186 (data zvernennya: 18.07.2018). 
11. Konvenciya pro oxoronu vsesvitn`oyi kul turnoyi i pry`rodnoyi spadshhy`ny`YuNESKO: mizhnar. dok. vid 16.11.1972. URL: http://zakon4.rada.gov.ua/laws/show/995_089 (data zvernennya: 08.07.2018)..rada.gov. ua/laws/show/995_186 (data zvernennya: 18.07.2018).

12. Kot S. I. «Kul`turni tsinnosti»: ponyattya i termin u konteksti povernennya ta restytutsiyi predmetiv kulıtury // Pratsi Tsentru pam»yatkoznavsta. 2011. Vyp. 20. S. 10-26.

13. Maksymov S. Y. Natsional`ni standarty otsinky: neobkhidnist zmin ta dopovnen : vystup na zasidanni kruhloho stolu «Zasady formuvannya kontseptual`nykh pidkhodiv do stvorennya systemy Natsional`nykh standartiv otsinky mayna ta maynovykh prav» 14 lypnya 2011 r. URL: http://www.vikno.com.ua/altfm/ viewtopic.php?p=88375\#88375 (data zvernennya: 22.07.2018).

14. Mizhnarodni dokumenty` [konvenciyi, xartiyi, rekomendaciyi z py`tan`oxorony` kul ‘urny`x cinnostej] // Pam >yatkoznavstvo: pravova oxorona kul turny`x nadban`: zb. dok. / In-t kul` turol. Akad. my`st. Ukrayiny`. Ky`yiv, 2009. - S. 220-360.

15. Osnovy zakonodavstva pro kulıturu: Zakon Ukrayiny vid 14.02.1992 \# 2117-XII, vtrata chynnosti vid 12.01.2011, pidst. 2778-17. URL: http://zakon2.rada.gov.ua/laws/show/2117-12 (data zvernennya: 11.07.2018).

16. Otsinka kulıturnykh tsinnostey / V. V. Indutnyy ta in. Kyyiv: TOV «Ayaks Print», 2006. 608 s.

17. Platonov B. O. Analiz prybutkovosti tvoriv mystetstva // Visnyk NAKKKIM. 2017. \# 1. S. 86-90.

18. Pro vy`vezennya, vvezennya ta povernennya kul` turny`x cinnostej: Zakon Ukrayiny` vid 21 ver. 1999 r. \# 1068-XIV, red. vid 06.08.2014, pidst. 1253-18. URL: http://zakon2.rada.gov.ua/laws/show/1068-14 (data zvernennya: 12.07.2018).

19. Pro zatverdzhennya Poryadku provedennya derzhavnoyi eksperty`zy` kul 'turny` $x$ cinnostej ta rozmiriv platy`za yiyi provedennya: post. KM Ukrayiny` vid 26 serp. 2003 r. \# 1343: red. vid 17.04.2013, pidst. 2332013p. URL:http://zakon3.rada.gov.ua/laws/show/1343-2003-\%D0\%BF (data zvernennya: 16.07.2018).

20. Pro kul 'turu: Zakon Ukrayiny` vid 14.12.2010 \# 2778-VI: red. vid 02.08.2018, pidst. 2481-19. URL: http://zakon2.rada.gov.ua/laws/show/2778-17 (data zvernennya: 11.07.2018).

21. Pro muzeyi ta muzejnu spravu: Zakon Ukrayiny` vid 29.06.1995 \# 249/95-VR: red. vid 24.02.2016, pidst. 955-19. URL: http://zakon3.rada.gov.ua/laws/show/249/95-\%D0\%B2\%D1\%80 (data zvernennya: 09.07.2018).

22. Pro oxoronu kul 'turnoyi spadshhy`ny`: Zakon Ukrayiny` vid 08.06 .2000 r. chy`nny `j, potochna red. 14.03.2018, pidst. 2289-19. URL: http://zakon5.rada.gov.ua/laws/show/1805-14 (data zvernennya: 01.07.2018). 23. Pro sudovu eksperty`zu: Zakon Ukrayiny`vid 25 lyut. 1994 r. \# 4038-XII, red. vid 20.01.2018, pidst. 2249-19. URL: http://zakon2.rada.gov.ua/laws/show/ru/4038-12 (data zvernennya: 23.07.2018).

24. Ramkova konvenciya Rady` Yevropy` pro znachennya kul`turnoyi spadshhy`ny` dlya suspil`stva : mizhnar. dok. vid 27.10.2005: dok. 994_719, chy`nny`j, potochna red., raty`f. vid 19.09.2013, pidst. 581-18. URL: http://zakon5.rada.gov.ua/laws/show/994_719 (data zvernennya: 24.07.2018).

25. Riabchykova F. D. Tlumachenn`a «predmeta muzeinogo znachenn`a» ta «muzeinogo predmeta» yak culturn`uh tsinnostei v ukrainskomy zakonodavstvi: muzeologichn`ui analiz // Pratsi Tsentru pam`yatkoznavstva: zb. nauk. pr. 36. Kyyiv, 2015. Vyp. 28. S. 36-46.

26. Sy`dor-Gibely`nda O. Dopovnennya do slovny`ka terminiv suchasnogo my`stecztva // Suchasne my`stecztvo. 2012. Vy`p. 8. S. 304-308.

27. Sy`dor-Gibely`nda O. Dopovnennya do slovny`ka terminiv suchasnogo my`stecztva // Suchasne my`stecztvo. 2013. Vy`p. 9. S. 135-142.

28. Slovny`k terminiv my`stecztvoznavcya-eksperta: dlya stud. specz. 8.02020501 "My`stecztvo", specializ. "My`stecztvoznavecz` -ekspert, ocinyuvach" / uklad.: V. A. Sivers, B. O. Platonov, N. I. Kravchenko [ta in.]. Ky`yiv: NAKKKiM, 2011. 124s.

29. Shman S. Yu. Kulıturolohichni aspekty derzhavnoyi ekspertyzy kulıturnykh tsinnostey v suchasniy Ukrayini: dys. ... kand. kulıt.: 26.00.01 - teoriya ta istoriya kulıtury. Kyyiv: NAKKIM, 2013. $192 \mathrm{s.}$

30. Berenson B. The study and criticism of Italian art. London: G. Bell and sons, 1902. $260 \mathrm{p}$.

31. Berenson B., Franchi R. Metodo e attribuzioni. Firenze: Arnaud, 1947. 233 p. 
Цыганок О. Б. Актуальные проблемы прикмадного искусствоведения сквозь призму современного законодательства Украины

Аннотация. Раскрыто содержание понятия «прикладное искусствоведение», предпринята попытка описания его задач и указано на его прямую связь с правовым полем, поднят вопрос терминологического несоответствия понятий в законодательстве Украины.

Ключевые слова: прикцадное искусствоведение, культурные ценности, юридическая терминология, законодательство Украины.

\section{Tsyhanok O. B. Pressing issues of applied art studies through the looking glass} of current Ukrainian legislation

Abstract. Meaning of the term "applied art studies" is discussed. The attempt to describe it's tasks is made, and it's direct connection with legal system is established. The question about adequacy of the Ukrainian legislative terminology is raised.

Keywords: applied art studies, cultural property, judicial terminology, Ukrainian legislature. 